Omni-Akuatika, 16 (2): 167 - 172, 2020
ISSN: 1858-3873 print / 2476-9347 online
Research Article
journal homepage: http://ojs.omniakuatika.net

\title{
Behavior Response of Blue Swimming Crab (Portunus pelagicus) to The Different Entrance Gates of Collapsible Pot
}

\author{
Henita Aditya ${ }^{1^{*}}$, Wazir Mawardi ${ }^{2}$, and Mochammad Riyanto ${ }^{2}$ \\ ${ }^{1}$ Marine Fisheries Technology Study Program, IPB Postgraduate School, Indonesia. \\ ${ }^{2}$ Department of Fisheries Resources Utilization, Faculty of Fisheries and Marine Science, IPB University Dramaga \\ Campus. Bogor 16680, West Java, Indonesia. \\ *Coresponding author: henita0607@gmail.com
}

Received 16 September 2020; Accepted 28 December 2020; Available online 31 December 2020

\begin{abstract}
The behavior of blue swimming crab (BSC) (Portunus pelagicus) to the collapsible pot is observed to redesign the entrance of the pot with high effectiveness. The purpose of this study is to identify the behavior response of BSC to the entrance gate of the collapsible pot by laboratory experiments. The behavior response of the BSC $(100-150 \mathrm{~mm}$ of carapace width $(\mathrm{CW}), \mathrm{n}=15)$ to the two angles of the entrance gate, that were $20^{\circ}$ as control and $40^{\circ}$ as a modification of the collapsible pot. The movement and speed of the crab to the entrance gate were observed by using CCTV Camera. The results showed that the percentage of crabs that failed to find the entrance was higher than crab that succeed to enter the pot. The crab that failed to find the entrance was $43 \%$ for control and $52 \%$ for modification pot, while the crab that succeed to enter was $24 \%$ for control pot and $19 \%$ for modification pot. There were five movement patterns of crab to enter the pot i.e. straight to entrance, side to entrance, side to side, entrance to side, and straight to side. The average speed of entrance crab was $127.89 \pm 46.48$ second for control, and $88.45 \pm 5.74$ second for modification pot.
\end{abstract}

Keywords: behavior, response, blue swimming crab, collapsible pot, Portunus pelagicus

\section{ABSTRAK}

Tingkah Laku Rajungan (Portunus pelagicus) terhadap bubu lipat diamati untuk mendesain ulang bagian konstruksi mulut agar dapat meningkatkan efektivitas bubu. Tujuan dari penelitian ini adalah untuk mengidentifikasi respons tingkah laku rajungan terhadap konstruksi mulut bubu lipat pada percobaan laboratorium. Respons tingkah laku rajungan (lebar karapas 100-150 cm, n=15 ekor) terhadap dua sudut lintasan masuk yaitu $20^{\circ}$ sebagai bubu kontrol dan $40^{\circ}$ sebagai bubu modifikasi pada bubu lipat. Pergerakan dan kecepatan rajungan menuju mulut bubu diamati dengan menggunakan kamera CCTV. Hasil penelitian menunjukkan bahwa persentase rajungan yang gagal menemukan bagian mulut bubu lebih tinggi dibandingkan dengan rajungan yang berhasil masuk kedalam bubu. Rajungan yang gagal menemukan mulut bubu sebanyak $43 \%$ untuk bubu kontrol dan $52 \%$ untuk bubu modifikasi, sedangkan rajungan yang berhasil masuk sebanyak $24 \%$ untuk bubu kontrol dan 19\% untuk bubu modifikasi. Terdapat lima pola pergerakan rajungan rajungan pada saat mencoba masuk pada bubu diantaranya straight to entrance, side to entrance, side to side, entrance to side dan straight to side. Kecepatan rata-rata rajungan masuk adalah $127.89 \pm 46.48$ detik untuk bubu kontrol dan $88.45 \pm 5.74$ detik untuk bubu modifikasi.

Kata kunci: Tingkah laku, respons, rajungan, bubu lipat, Portunus pelagicus

\section{Introduction}

Blue swimming crab (Portunus pelagicus) is one of the important fisheries commodities in Indonesia. A collapsible pot is a dominant fishing gear to catch BSC. Research on how to increase catch effectiveness of collapsible pot has been done in field experiments. The use of 
a circular funnel trap can reduce the number of spawn blue swimming crab (Boesono et al., 2018). The effectiveness of using passive fishing gear such as a pot is influenced by the type, species, habitat, behavior, size, and specifications of the fishing gear (Atar et al., 2002). The success of catching activity using pot is influenced by entrance construction (Rompis et al., 2019). The improvement of pot design was carried out in the entrance because crab enters the pot by crawling up (Susanto et al., 2014). The physiological and behavioral response of the BSC to the fishing gear is the basic information to increase the catch effectiveness and efficiency (Purbayanto et al., 2010). Crab behavior is an important factor in determining the design and entrance position of the collapsible pot. Therefore, research on the behavior response of BSC in the laboratory is still needed to be used to design effective entrance by fishermen. The purpose of this study is to identify the behavior response of BSC to the entrance gate of the collapsible pot by laboratory experiments.

\section{Material and Methods}

\subsection{Blue Swimming Crab}

The total crab used in the laboratory experiment was 15 individuals with carapace width (CW) of $100-150 \mathrm{~mm}$. The crab was adapted and acclimatized in the tank at Salinity of $30-35 \%$ and temperature range of $28^{\circ}-$ $30^{\circ} \mathrm{C}$. The experiment was conducted on January - February 2020 in the laboratory of BAPPL, Serang city Banten Province.

\subsection{The Collapsible Pot}

The design of the pot (Figure 1) for laboratory experiment simulation using two different angles of the entrance gate, $20^{\circ}$ as control and $40^{\circ}$ as a modification. The angle size of $20^{\circ}$ was the angle size generally used by fishermen, while the angle size of $40^{\circ}$ was the result of observation in the laboratory. The pots had the same dimension with a size of 46 $\times 32 \times 19 \mathrm{~cm}$ in Poly Ethylene 210D/6, and the mesh size was 1.25 inch, which had two open funnel entrances.

\subsection{Laboratory Experiments}

The pot was set in a rectangle tank (length $\times$ width $\times$ depth, $200 \times 100 \times 50 \mathrm{~cm}$ ), Figure 2 shows an illustration of pot and BSC position in the tank. Crabs were fasted for a day before observation to make crabs attracted and approached the baited-pot. Observations were conducted when the crab moved from the start position to the pot position. The pot was set at $05.00 \mathrm{pm}$, and was hauled at $06.00 \mathrm{am}$. It was conducted as fishing by the pot in the fishing ground (at $05.00 \mathrm{pm}$ and ended at $05.00 \mathrm{am}$ ) (Irnawati et al., 2014). The Pot observations were carried out alternately. The BSC behavior was recorded using a CCTV camera that was set 1 meter above the tank. The bait was placed in the middle of the pot to attract the crab to enter and trapped inside. The crab approached the pot because of the stimulation of olfaction sense (antennules) (Anraku et al., 2001; Archdale et al., 2006).

\subsection{Data Analysis}

The data was taken from the video recording of BSC behavior was analyzed using

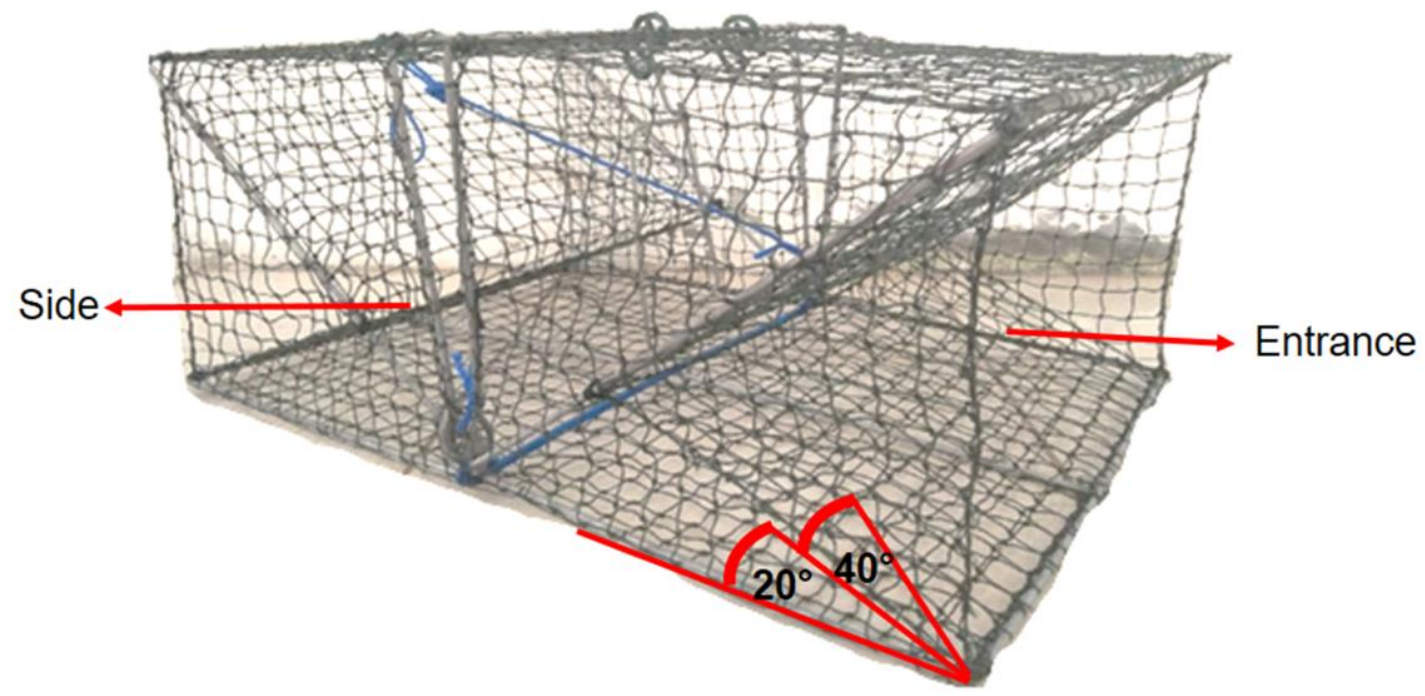

Figure 1. The collapsible pot and track angle illustration 


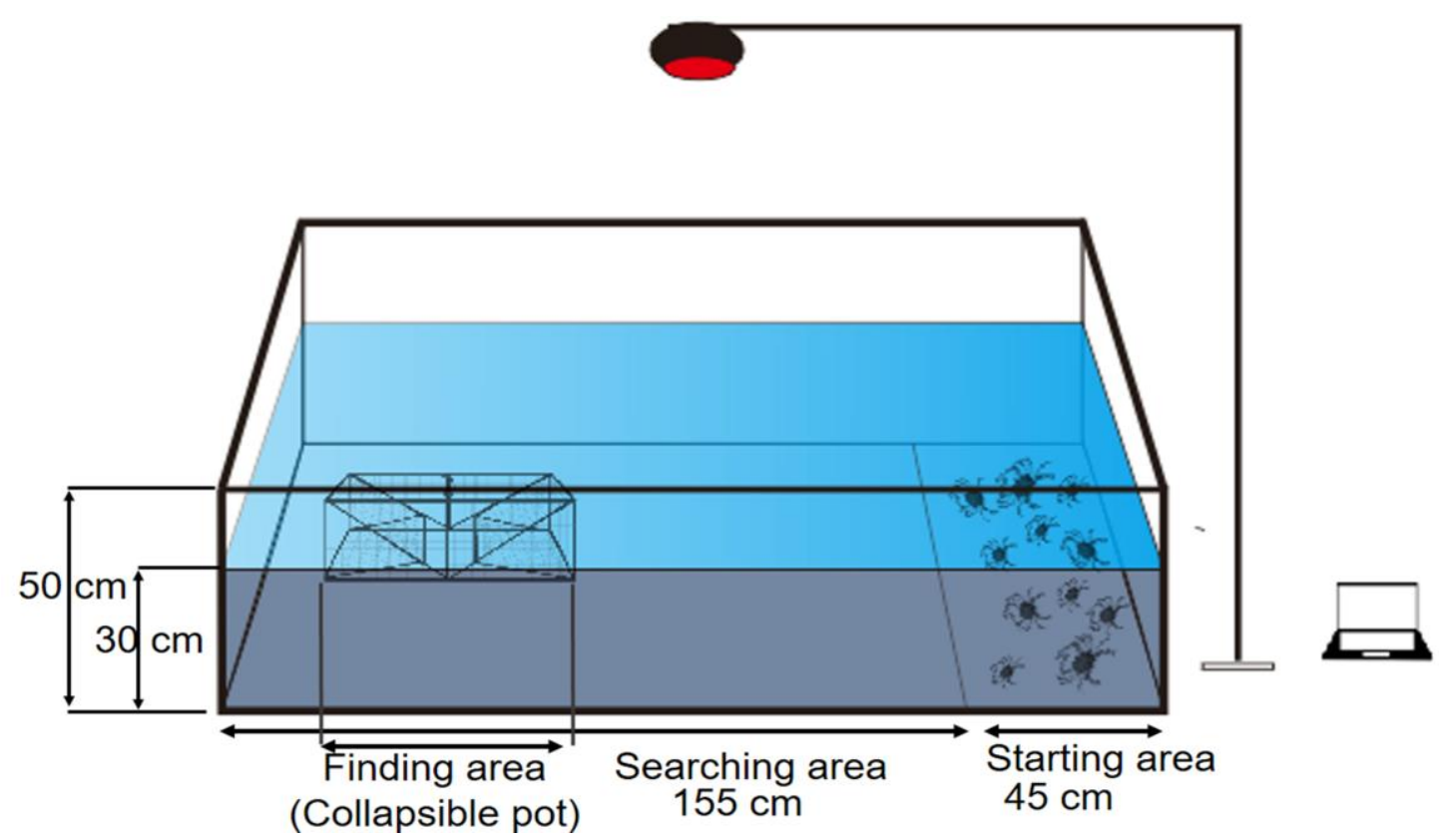

Figure 2. Experiment setup to observe the behavior of BSC

frame by frame video analysis. The data analyzed were 1) the proportion of success crab entered to the pot, 2) the speed of the crab entered to the pot, and 3) response and behavior of swimming crab. The response of the crab to the pot is a pattern of arrival of the crab when trying to enter the pot. The crawling speed was counted from the crab touched on the bottom of the track until it passed the funnel. Statistical analysis used was Mann-

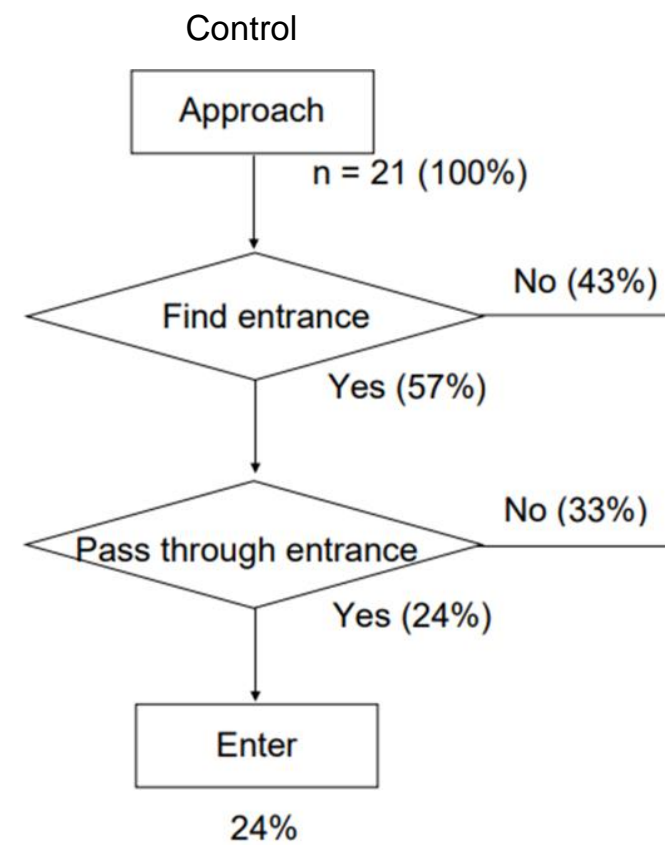

Whitney to test the difference in crawling speed on a different angle.

\section{Results and Discussion.}

3.1. The proportion of success BSC entered the pot

The observation results (Figure 3) showed that the percentage of failed crabs to find the entrance was higher than succeed enter the

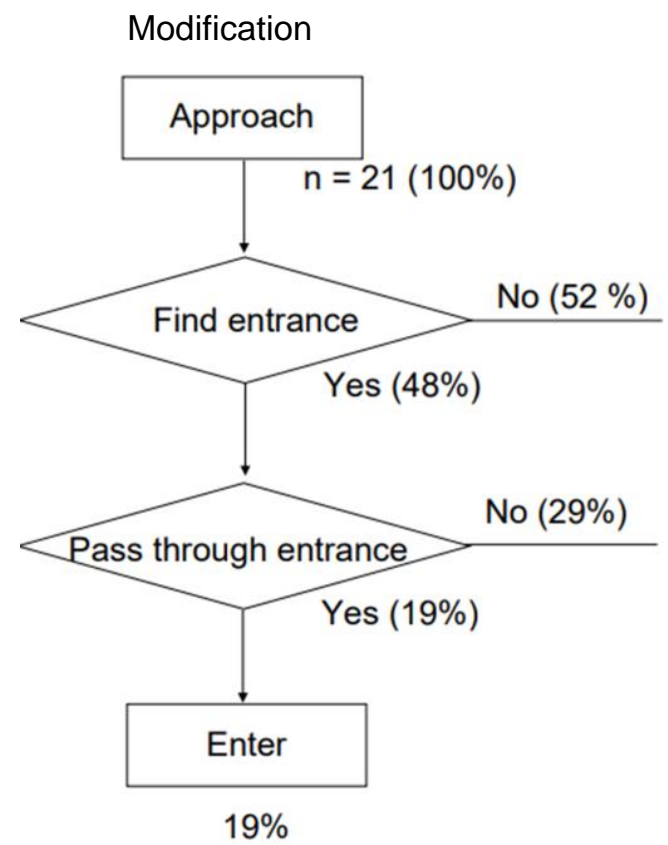

Figure 3. The proportion of success of the BSC enter the pot 
pot. The crab that failed to find the entrance was $43 \%$ for control and $52 \%$ for the modification pot, while the crab that be successful to enter was $24 \%$ for control pot and $19 \%$ for modification pot. Percentage of failure of crabs in finding the entrance of box shaped pot 54\% (Archdale et al., 2003). The dominant arrival of crabs was on the side of the pot, and it was a failure factor because the crab was difficult to find the entrance from the side. According to Archdale et al., (2003), showed that the first arrival of crab was on the side of the pot. The crab must walk along the pot wall to find the entrance. The average time to search for the entrance was $1.7 \mathrm{~min}$ and 2.9 min (Zhou and Shirley, 1997). The swimming crabs failed to enter the pot because the crab did not find the entrance (Martasuganda, 2008).

The entrance position that is easy to find would increase the crab's catches (Jayanto et al., 2018). The position of the first crab arrival at the pot give influence to the success rate of crabs to enter the pot. At the time of testing modified pot the arrival position of the crabs tends to be on the side pot so that it makes the crab experience failure. This suggested that the increase of crabs trapped in the pot was influenced by the entrance position. If the entrance position was easy to find, it would increase the effectiveness of the pot.

\subsection{The speed of BSC entered the pot}

The statistical analysis results showed that the crawling speed of crab to a different angle entrance pot was significantly different ( $p$ $>0.05$ ). The crawling speed of the crab with angle of $40^{\circ}$ was faster than $20^{\circ}$. The average speed of entrance crab was $127.89 \pm 46.48$ second for control, and $88.45 \pm 5.74$ second for modification pot (Figure 4). The pot with an entrance angle of $40^{\circ}$ was easy to be passed by adult crab and more difficult to pass subadult crabs (Fitri et al., 2017). While the control pot with an angle of $20^{\circ}$ and a narrow entrance caused the crab to stay longer on the track angle. The crabs were easier to reach bait from the top in the low angle. The crab would leave the pot if they were difficult to enter. The narrow slit made carapace and chelipeds entangled on the netting (Archdale et al., 2006). Based on the results, the entrance with angle of $40^{\circ}$ was suggested to be used to increase the speed of crab enter the pot. The ease construction of modified entrance for crabs to pass through can increase the number of catches. The percentage of crabs cannot

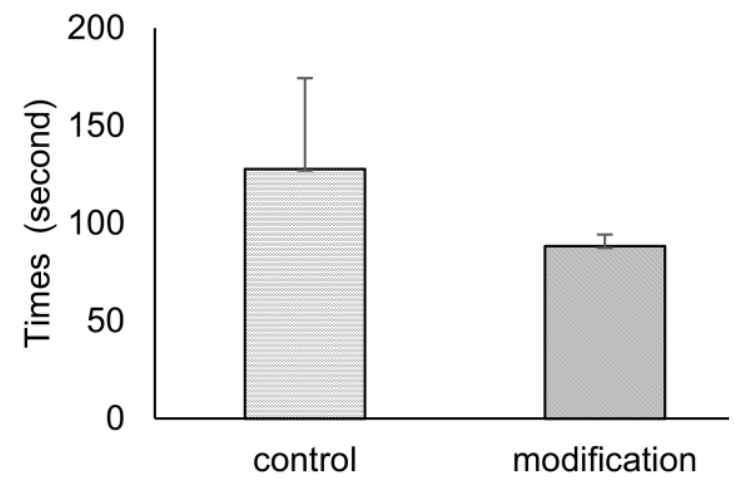

Figure 4. Speed of the BSC enter the pot

pass through the entrance to the control pot is higher than modified pot. Open funnel entrance was more efficient for catching (Archdale et al., 2003).

\subsection{Response and behavior of swimming crab.}

Based on the behavior response of crab to the pot, the movement patterns of crab were not different between the control and modification pot because the pot had the same constructions and position entrance. The dominant arrival of crabs was on the side of the pot. The crabs process enters the pot by tracing the wall of the pot to find the entrance (Archdale et al., 2003). Based on observations of the movement patterns of crabs in laboratory experiments consisting of 5 patterns of crabs to enter the pot shown in Figure 5.

a) Straight to entrance. The crab ran from the start area to the pot and the position of crab was straight to the entrance pot, then the crab approached the entrance of the pot and started to crawl.

b) Side to entrance. The crab found the entrance with tracing the wall of the pot. Crab approached the pot by stopping occasionally. Furthermore, the crab approached the side of pot. The crab walked by tracing the wall of the pot and succeed found the entrance of pot.

c) Side to side. The crab moved toward pot position. Then, approached the side position of the pot and moved to the right and left side to looking for access to enter the pot, then went away from the pot. However, after a few minutes, the crab approached back the pot in the same position (on the side of the pot) and had the same behavior as before and still failed to enter. The average crab move and trying to reach bait on the side position for 1 minute 46 seconds.

d) Entrance to side. The crab moved and stopped at the entrance and tried to enter, 


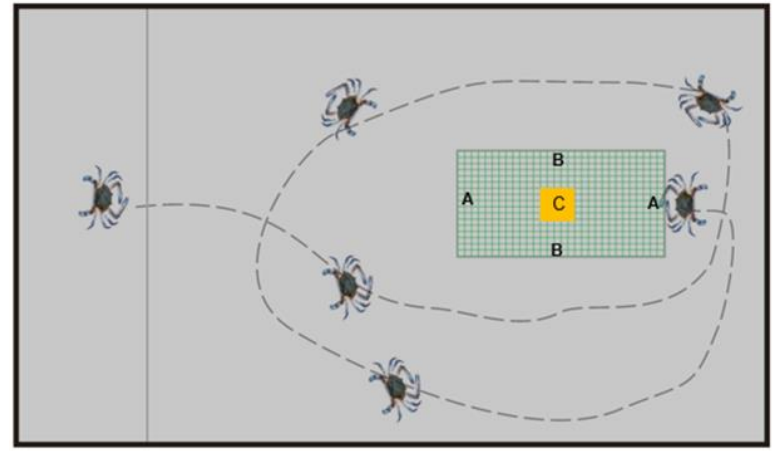

Straight to Entrance

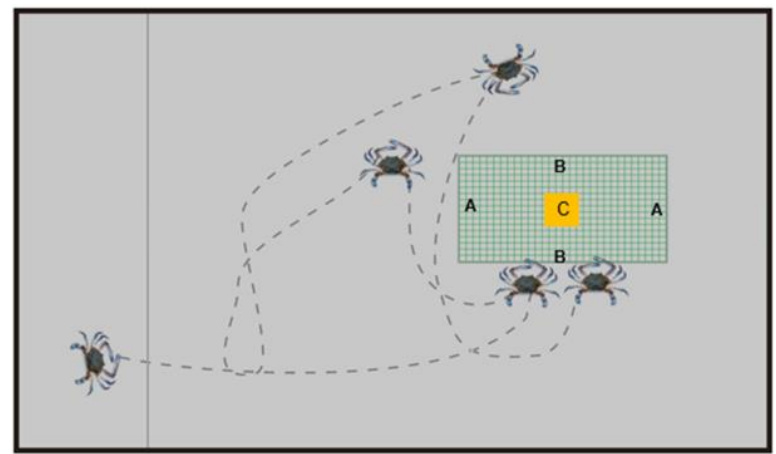

Side to Side

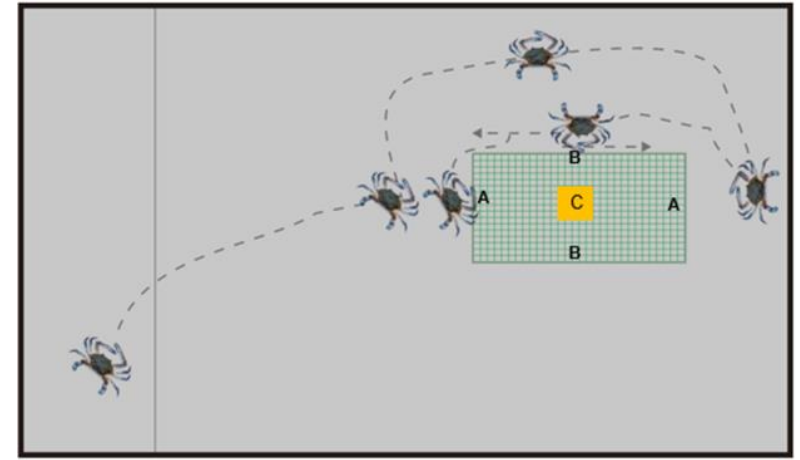

Side to Entrance

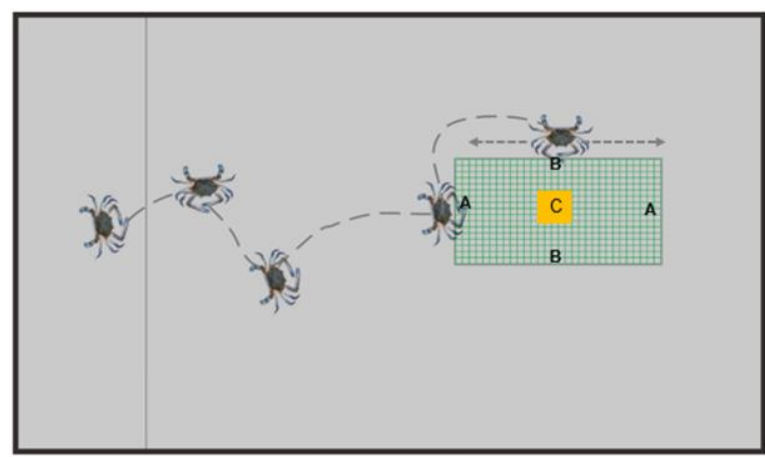

Entrance to Side

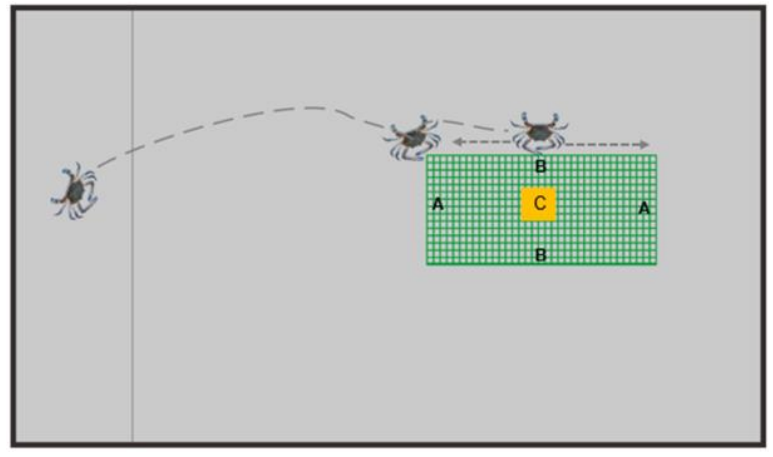

Straight to Side

Figure 5. Movement pattern of crab to the pot (A) Entrance (B) side (C) Bait

but it was still difficult. Then, the crab came out from the entrance and approached the side of the pot and tried to reach the bait. On the side of the pot, crabs trying to reach bait and move to the right and left side to search access to enter the pot.

e) Straight to side. Crabs moved directly from the start area to the side of the pot. In this position, the crab moved to the left and right tried to get into the pot. The behavior of crabs when touching the pot, the crab will try to reach bait with insert a claw through the net.

\section{Conclusion}

A comparison of the crab behavior response to a different angle had the same response. Where the percentage of crabs that failed to enter was higher than crab that successful to enter the pot. There were five movement patterns of crab to enter the pot i.e. straight to the entrance, side to entrance, side to side, entrance to the side, and straight to side. The same construction and design of the pot caused no difference on the crab movement pattern for the control and modification pots. The use of angle $40^{\circ}$ in the collapsible trap could increase the effectiveness of crawl time of the crab. 


\section{References}

Anraku, K., Archdale, M.V., Mendez, B., 2001. Crab Trap Fisheries: Capture Process and an Attempt on Bait Improvement. UPV J. Nat. Sci 6, 121-129.

Archdale, M.V., Anraku, K., Yamamoto, T., Higashitani, N., 2003. Behavior of the Japanese Rock Crab 'Ishigani Charybdis japonica Towards Two Collapsible Baited Pots: Evaluation of Capture Effectiveness. Fish. Res. 69, 785-791.

Archdale, M.V., Kariyazono, L., Anasco, C.P., 2006. The Effect of Two Pot Types on Entrance Rate and Entrance Behavior of The Invasive Japanese Swimming Crab Charybdis Japonica. Fish. Res. 77, 271274.

Atar, H.H., Olmez, M., Bekcan, S., Secer, S., 2002. Comparison of Three Different Traps for Catching Blue Crab ( Callinectes sapidus Rathbun 1896 ) in Beymelek Lagoon. Turkish J. Vet. Anim. Sci. 26, 1145-1150.

Boesono, H., Hapsari, D.M., Dian, A., Fitri, P., Eko, K., 2018. Preserving Blue Swimming Crab (Portunus pelagicus ): Its Conservation using Trap Modifications in Betahwalang, Demak. Pertanika J. Trop. Agric. Sci. 41, 879-888.
Fitri, A.D.P., Boesono, H., Sabdono, A., Supadminingsih, F.N., Adlina, N., 2017. The Mud Crab ( Scylla serrata) Behavior in Different Inclination Angles of Funnel and Escape Vent for Trap Net. AACL Bioflux 10, 191-199.

Irnawati, R., Susanto, A., Maesaroh, S.L.A., 2014. Mud Crab Fishing Time in Lontar Water Serang Regency Banten. Perikan. dan Kelaut. 4, 277-282.

Jayanto, B.B., Prihantoko, K.E., Triarso, I., Kurohman, F., 2018. The Effect of Funnel Addition on Trap Toward catch of Blue Swimming Crab in Rembang Sea waters. Saintek Perikan. 13, 100-104.

Martasuganda, S., 2008. Traps.Departemen Pemanfaatan Sumberdaya Perikanan. Cetakan ketiga. Institut Pertanian Bogor.

Rompis, J., Paransa, I.J., Pamikiran, R.D.C., 2019. The Effect of Entrance Position of Floating Trap on Fish Catch in Shallow Water Raft. Ilmu dan Teknol. Perikan. Tangkap 4, 1-5.

Susanto, A., Irnawati, R., Sasmita, A., 2014. Crawling Speed of Mud Crab: Scylla serrata Indentification at Different Mesh Size Pattern and Inclination Angle. J. IImu Pertan. dan Perikan. 3, 11-17.

Zhou, S., Shirley, T.C., 1997. Performance of two red king crab pot designs. Can. J. Fish. Aqautic Sci. 54, 1858-1864. 